\title{
Market signals and subject choice
}

from Richard Pearson

\section{The involvement of prospective employers in sponsoring students in higher education can lead to improvement in courses in general, as well as benefiting individuals.}

IN the $1980 \mathrm{~s}$, teachers and educationalists are expected to consider 'market signals' when planning course provision and curricula. Likewise students entering higher education are expected to adjust their subject preferences by noting changes in relative salaries, career prospects and unemployment rates. The hoped-for outcome is that educational output becomes more closely aligned to economic and labour market needs. As well as offering improved career prospects and higher salaries, employers are increasingly using sponsorship of students in higher education as a means of attracting those with scarce skills (Nature 307, 488; 1984). To aid this process, in 1984 the UK Department of Education and Science increased the amount a student could receive from an employer by way of a term-time bursary from $£ 915$ to $£ 1,600$ a year, with the secretary of state commenting "I am sure that these increased sponsorship levels will help to attract able students to pursue courses of great importance both to them, to employers, and to the economy..."

For individual employers, the prime motive in sponsoring undergraduates is to meet their own recruitment needs. They are now spending over $£ 10$ million each year on such activities. In 1984, one in four final-year engineering undergraduates was being sponsored, while the number of finalyear electronics graduates receiving sponsorship increased by over 70 per cent in the past five years. A report shortly to be published by the Institute of Manpower Studies (see Table 1) examines the extent to which this market signal is also affecting the subject choices of those entering higher education and thus expanding the overall supply of students in poorly patronized subjects.

There was clear evidence that the number of engineering students wanting sponsorship was far greater than the number of

Table 1 Students' views on the benefits of sponsorship

$\begin{array}{lr}\text { Extra money } & 55 \% \\ \text { Practical experience } & 41 \% \\ \text { Future job prospects } & 29 \% \\ \text { Vacation job } & 24 \% \\ \text { Better training } & 14 \% \\ \text { Other } & 5 \%\end{array}$

Percentages are proportions of sponsored students only. These data, and data in Table 2, are from "Employers Sponsorship of Undergraduate Engineers, by A. Gordon, R. Hutt \& R. Pearson (Gower, Aldershot, in the press). sponsorship places available. Given the real and perceived benefits of employer sponsorship - guaranteed industrial training, extra income, close links with an employer, and the probable offer of a job on graduation - this was not surprising (Table 1). The offer of sponsorship affected one in four students' choice of course and institution (Table 2). The biggest impact was on the choice of institution, although a significant minority switched to sandwich courses as a result of sponsorship. Of those switching subject, for a few the shift was fairly dramatic, for example from biochemistry to mechanical engineering, but for many it meant a more limited adjustment.

The impact on students depended to some extent on the way in which the employers' lists of preferred courses were drawn up. The criteria for inclusion were not only the perceived relevance or reputation of the course, but also the apparent status of the institution, the kind of student believed to be attracted to and accepted by it, the historical experience of senior managers and the recent experience of graduate recruitment personnel. Only a minority of employers included polytechnics on their preferred list.

Sponsorship can however cause difficulties for those not directly involved. Thus non-sponsored students on sandwich courses were finding it increasingly difficult to find training placements. Some teaching staff were concerned that links with a single employer might also make a student's industrial experience excessively narrow arid in some cases unduly influence course content and pattern. The view was also expressed that because sponsorship focuses student and employer attention on certain, usually well known, institutions and courses, it can inhibit the development of new courses.

Because of sponsorship arrangements, each year a significant proportion of engineering graduates move directly into jobs with their sponsoring employer and effectively do not become job seekers in the annual graduate recruitment round. As a result, the number of newly qualified graduates actively seeking jobs in the labour market on graduation is considerably lower than the number graduating each year. Thus in 1983, some 500 or more newly graduating electrical/electronics engineers took jobs with their sponsoring employer while a further 600 to 800 chose to go on to research or further training or take jobs outside engineering. This meant that employers seeking to fill direct-entry appointments were recruiting from a pool of active job-seekers totalling some 2,000 rather than 3,100 newly graduating electrical/electronics engineers.

The sponsored graduates withdrawn from the open market in this way were not evenly distributed. They tended to be among the most highly qualified young engineers in terms of course entry qualifications, and were frequently concentrated in some of the most industrially oriented and often more prestigious departments

Table 2 Influence of sponsorship on students' choices

\begin{tabular}{ll}
\hline Subject choice & $14 \%$ \\
Type of course & $25 \%$ \\
Institution & $22 \%$ \\
\hline
\end{tabular}

Percentages refer to sponsored students only.

and institutions. They had also often received relevant industrial training. Nonsponsoring employers seeking to recruit from these courses, and wanting a spread of ability and educational background in their new graduate recruits, will therefore have had increased difficulties.

Overall it is clear that the availability of sponsorship has led directly to some students switching subjects and courses, a significant proportion in the case of production engineering, and acted as a positive signal to potential students about the subjects and courses employers value most. Sponsorship thus serves to increase, albeit by a small amount, the pool of students seeking to study in disciplines of the highest relevance to employers.

The content and pattern of degree courses is also being affected through the involvement of sponsoring employers, increasing their relevance to that group of employers. If these are also the most farsighted and thoughtful employers in relation to engineering education, then the industry at large can be expected to benefit. However, sponsorship has most relevance and impact on market share, and on the quality of graduates recruited, aiding primarily the sponsoring employer and those directly involved, and has less impact on market size and the overall pool of engineering talent in the economy.

Richard Pearson is at the Institute of Manpower Studies, Mantell Building, University of Sussex, Brighton BNI 9RF, UK. 